\title{
PTERIDOPHYTES OF THE OKAVANGO DELTA, BOTSWANA (SOUTHERN AFRICA)
}

\author{
by \\ EFRÉN VEGA HERNÁNDEZ ' \& RODULIO CAUDALES 2 \\ ' Departamento de Biología, Universidad de Puerto Rico, P. Box 23360, San Juan, Puerto Rico, 00931-3360 USA \\ ${ }^{2}$ Department of Science and Technology, Colegio Universitario del Este, Ana G. Méndez University System, \\ P. Box. 2010, Carolina, Puerto Rico, 00984-2010 USA
}

\begin{abstract}
Resumen
Vega Hernández, E. \& R. CaUdales (2001). Los pteridofitos del delta del Okavango, Botsuana (sur de Âfrica). Anales Jard. Bot. Madrid 58(2): 31 1-323 (en inglés).

Se estudian los pteridófitos del delta del Okavango, uno de los deltas interiores más grandes del mundo. Se citan 15 especies, incluidas en 10 géneros y 9 familias. Se aportan descripciones, claves de identificación, datos sobre la distribución y ecología. y mapas de distribución detallada de cada una de las especies.

Palabras clave: Pteridophyta, delta del Okavango, Botsuana.
\end{abstract}

\begin{abstract}
Vega Hernández, E. \& R. Caudales (2001). Pteridophytes of the Okavango Delta, Botswana (Southern Africa). Anales Jard. Bot. Madrid 58(2): 311-323.

The Okavango Delta in Botswana constitutes one of the larger inland deltas in the world. Fifteen species of fern were found in this ecological system integrated into 10 genera and 9 families. Included in this report are descriptions of each family, genus and species. Also given are artificial keys to the genera, as well as keys for genera and species within the family when necessary. A documented distribution and ecological notes for each species also appears.
\end{abstract}

Key words: Pteridophyta, Okavango Delta, Botswana.

\section{INTRODUCTION}

Okavango, one of the larger African rivers, has as its head waters the Cuito and Cubango Rivers in N Angola. These rivers flow from the highland of Planalto Central in $\mathrm{N}$ Angola and join in S Angola to form the Okavango River. In Botswana the Okavango River runs between two parallel faults in the Panhandle which control the direction of the river (Ross, 1992). Close to the end of the faults the Okavango is divided into three major rivers forming a broad delta. Due to the low slope of the Kalahari Desert, the Delta starts S of the Caprivi strip in Namibia and dies out at the SE in the Kunyere and Thamalakane Faults, Botswana. The delta forms a unique environment comprised of $6,000 \mathrm{~km}^{2}$ of permanent swamps, $10,000 \mathrm{~km}^{2}$ of permanent islands or peninsulas with dry savanna, and $10,000-12,000 \mathrm{~km}^{2}$ of seasonal swamps (MCCARTHY \& al., 1993).

The geological composition of the Delta is made up of rocks composed of granitoic gneiss of the Archean Basement Complex. The strata are variably metamorphosed, comprized of quartz schists, quartzites and dolomitic marbles of the late Pre-Cambrian age (HuTCHINS \& al., 1976).

The climate of the Okavango Delta is semi- 
arid with an average rainfall of $500 \mathrm{~mm} \mathrm{y}^{1}$ (SiltTSHENa \& McLeOd, 1992). Water level is affected by the rainy season in Botswana between November and March, and by a flooding period from May to July due to the rainy period in central Angola.

\section{Vegetation of THE Okavango Delta}

The Okavango Delta (SмITH, 1976) comprises several associations in a complex of permanent swamps, open water, seasonal swamps and floodplain. The permanent swamps are always under water and never dry out. The floodplains are areas liable to inundation, which when flooded, remain so only for part of the year. The seasonal swamps are in an intermediate category.

The vegetation of permanent swamps is dominated generally by communities of Cyperus papyrus, Phragmitis australis and Typha latifolia subsp. capensis. Open water communities are composed in general of Cyperus nudicaulis, Scirpus cubensis, as well as Brasenia schreberi, Nymphaea coerulea, Najas pectinata, Ceratophyllum demersum, Lagarosiphon ilicifolius and Utricularia species diverses. Dominant species of the seasonal swamps are Scirpus inclinatus and Cyperus articulatus. Transional zones between permanent and seasonal swamps are characterized by Panicum repens, Oryza longistaminata, Leersia hexandra, Rhynchospora, Fimbristylis and Fuirena species diverses, Nymphaea coerulea, Potamogeton thumbergii, Nymphoides indica and Caldesia reniformis. Floodplains contain mostly grasslands covered by Hyparrhenia rufa, Cymbopogum excavatus as well as species of Vossia, Echinocloa, Leersia, Oryza and Paspalum. Lastly, the islands and mainland edges are usually marked by a tree line composed of species of Hyphaene petersiana, Phoenix reclinata, Ficus verriculosa and others.

Several studies of regional floras have been published on the Pteridophytes of Southern Africa (BURRows, 1990; SCHELPE, 1970; LAUNERT, 1968, 1975; SCHELPE \& ANTHONY, 1986). However, there are few publications on the flora specifically of the Okavango Delta in Botswana (SMITH, 1976), and what has been described is scattered in the scientific literature. There is yet no comprehensive study of the ferns of the Delta. Four new records of ferns for Botswana have been reported recently, including Marsilea minuta $L$. found in the Okavango Delta (VEGA HERNÁNDEZ \& al., 1997). The present report describes the ferns of the Okavango Delta, including information on their habitat and ecology, as well as map distributions.

\section{METHODS}

A series of explorations were carried out in the Okavango Delta, Botswana, with the objective of searching specifically for ferns. Regional herbaria were consulted as well, including the Herbarium of the University of Botswana, the Herbarium of the National Museum of Gaborone, Botswana, the National Botanical Institution Herbarium of Pretoria, South Africa, National Herbarium and the Botanic Garden of Harare, Zimbabwe. Scientific consensus classification of Pteridophyta was taken from HENNIPMAN (1996). The pteridologycal flora of the Okavango Delta is integrated into 7 families, 10 genera and 15 species.

\section{KEY TO THE GENERA OF PTERIDOPHYTA IN THE OKAVANGo DELTA}

1. Plants floating 2

- Plants rooted in mud or terrestrial ................. 3

2. Leaves in whorls of three, two floating, one submerged 9. Salvinia

- Leaves not in whorls, two lobed ..... 10. Azolla

3. Fronds simple, sporangia in a spike 1. Ophioglossum

- Fronds divided 8. Marsilea

4. Fronds bearing 4 leaflets 4

- Fronds pinnate …………………………….

5. Fronds succulent, fertile fronds thinly divided 3. Ceratopteris

- Fronds not succulent ... 6

6. Sori linear ..................................................... 7

- Sori discrete ……......................................... 8

7. Final segments articulated ............... 6. Pellaea 
- Final segments not articulate, conspicuously sterile 5. Pteris

8. Sori marginal, covered by the reflexed margin

- Sori dorsal in veins or in a vein-ending 4. Adiantum

9. Sori dorsal in veins, fronds bipinnatifid

7. Thelypteris

- Sori in a vein-ending, 3-4 pinnatifid

2. Microlepia

\section{OPHioglossaceaE}

Terrestrial or epiphytic plants. Rhizome short, fleshy, bearing roots more or less fleshy. Fronds one or several; frond development not circinate; sterile blades entire or divided; fertile blades erect or divergent spore-bearing spikes or panicle. Sporangia sessile or subsessile. Spores all similar.

A worldwide family of three genera and 60 or more species (Proctor, 1989). Only one genus occurs in Southern Africa.

\section{Ophioglossum L.}

Sterile blade simple or palmately lobed, sessile or short stalked, with reticulate venation. Fertile blades spicate. Sporangia subglobose, in two marginal rows. Spores globose, trilete.

A genus with more than 30 species distributed almost around the world (except Arctic and Antarctic regions) (PROCTOR, 1989). Two species occur in the Okavango Delta.

\section{KEY TO THE SPECIES OF OPHIOGLOSSUM IN THE OKaVANGo DELTA}

1. Rhizome more less linear, roots spaced

- Rhizome orbicular, roots wiry

1. O. polyphyllum

2. O. costatum

1. Ophioglossum polyphyllum $\mathrm{A}$. Br. in Seub., Fl. Azor.: 17 (1884)

Rhizome slender up to $60 \mathrm{~mm}$ long. Sterile blade $20-110 \times 5-30 \mathrm{~mm}$, usually narrowly elliptic to lanceolate, apex usually acute, occasionally obtuse, base narrowly to broadly cuneate, texture fleshy. Spikes $22-120 \mathrm{~mm}$ long, sporangia $12-46$ pairs.
Seasonally flooded ponds, pans and swamps, usually with sandy soil. South Africa (Transkei), Lesotho, Namibia, Botswana, Zimbabwe, Mozambique and most Africa to Algeria in the N, but excluding the $\mathrm{W}$ and $\mathrm{C}$ African countries. Also Cape Verde Islands, Canary Islands and St. Helena, Saudi Arabia, Afghanistan and India. OKavango DElta: Recorded in Moremi Wildlife Reserve. Vouchers: Gess 8383 (PRE), Strey 2091 (PRE), Evans 3268 (16) (PRE), Hansen 3231 (PRE), Buerger 1113 (PRE) (figs. 1, 2).
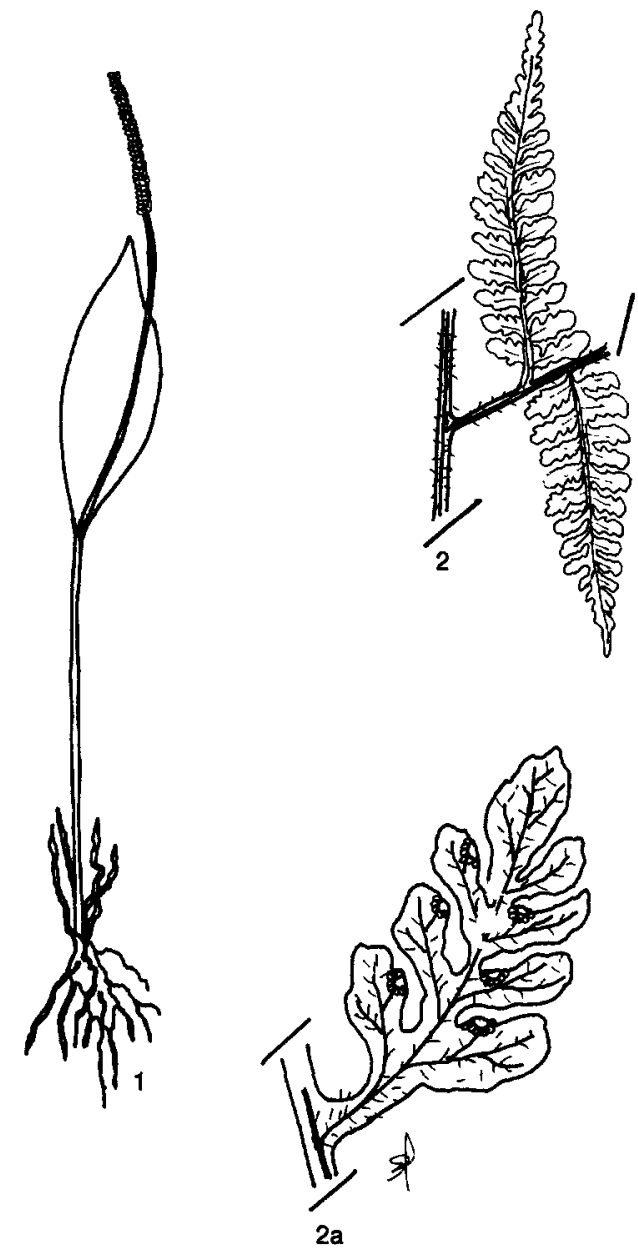

Fig. 1.-Ophioglossum polyphyllum: 1, plant. Microlepia speluncae: 2 , segment of frond; $2 \mathrm{a}$, detail of pinnule. 


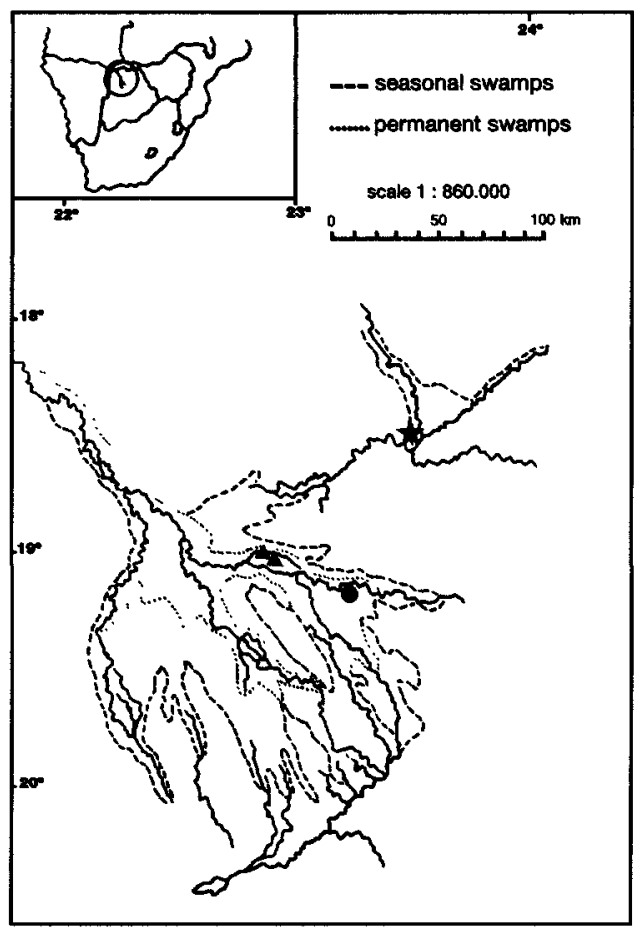

Fig. 2.-Distribution of Ophioglossum costatum (•), $O$. polyphyllum ( $\star$ ) and Microlepia speluncae $(\boldsymbol{\Lambda})$ in Okavango Delta.

2. Ophioglossum costatum R. Br., Prodr. Fl. Nov. Holl.: 163 (1810)

Rhizome orbicular, 4-14 $\mathrm{mm}$ in diameter; roots densely clustered. Leaves 1-4, commonly 2 , erect; petiole $10-50 \mathrm{~mm}$ long; sterile blade $30-100 \times 15-30 \mathrm{~mm}$ long, narrowly elliptic, oblong-lanceolate, apex acute, base rounded-cuneate. Spikes 50$250 \mathrm{~mm}$ long, 30-60 pairs of sporangia, apex acute.

Seasonally flooded pans and wet sandy soils, with preference for shaded places. South Africa (C and E Transvaal), Botswana, Zambezi Valley of Zimbabwe and Mozambique, Malawi, Zambia. Widespread in tropical Africa, S Asia and Australia. OKAVANGo DELTA: Recorded in the Kwando River (Kwando Hunters). Voucher: Smith 2217 (PRE) (fig. 2).

\section{DennstaedtiaCeae}

Rhizomes hairy creeping or erect. Fronds large, 3-4 pinnate. Veins free or anastomosing. Sori marginal, submarginal or superficial near margin, small, or subcircular to elongate; indusium absent, ovate and shallowly cupped, linear; soral paraphyses present or absent.

\section{Microlepia Presl.}

Rhizome creeping. Fronds closely spaced; stipe slightly pubescent; blades $1-4$ pinnate, often large, delicate, pubescent. Sori intramarginal, borne on a vein ending; indusium small, membranous, opening outwards.

A genus of about 45 species of worldwide distribution, but mostly of the Old World tropics. Only one species occurs in the Okavango Delta.

1. Microlepia speluncae (L.) T. Moore, Ind. Fil.: 93 (1857)

Rhizome creeping. Fronds covered by pale hairs; stipe up to $1 \mathrm{~m}$ long; lamina 4 pinnatifid to 4 pinnate, pinnae oblong to oblong lanceolate. Sori situated at the end of the veins, indusium obtriangular.

Permanent swamps, confined to moist and shaded places. Pantropical. South Africa (Natal and Transvaal), Namibia, Botswana, C Africa and Sao Tome. Also Madagascar, Seychelles and Comoro Islands. OKAVANGo DELTA: Recorded in Maunachira River. Vouchers: Chase 10175 (PRE), Whik 10419 (PRE) (figs. 1, 2).

\section{Pteridaceae}

Rhizome erect, decumbent to creeping, scales linear to ovate. Fronds usually 1-4 pinnate; veins free or anastomosing. Sori on the abaxial surface of the segments, along the veins, at vein margins, or on a usually marginal vascular commissure, or on the sporangia distant or contiguous to anastomosing veins. Exindusiate, or the 
recurved margin modified as a marginal indusium.

A large and diverse family of nearly worldwide distribution with some 35 genera. Four genera occur in the Okavango Delta.

\section{KeY TO THE GENERA OF PTERIDACEAE IN THE OKAVANGO DELTA}

1. Sori located along veins 3. Ceratopteris

- Sori located near margin or in reflexed flaps .. 2

2. Sori on the under side of sharply reflexed marginal lobes, venation dimidiate or flabellate 4. Adiantum

- Sori near margin, venation free or anatomosing

3. Ultimate fertile segment with a distinct entire to serrated sterile apex 5. Pteris

- Ultimate fertile segment without a distinct sterile apex 6. Pellaea

\section{Ceratopteris Brongn.}

Aquatic or subaquatic ferns, subsucculent with soft fronds. Rhizome short, floating. Fronds dimorphic; sterile blades simple to 3 pinnate, broadly divided, bearing proliferous buds; fertile blades longer than the sterile ones, finely divided, margins reflexed, enclosing 1-4 rows of sporangia.

A genus of perhaps four species, widely distributed (Proctor, 1989). One species occurs in the Okavango Delta.

\section{Ceratopteris cornuta (Beauv.) Le Prieur,} Ann. Sci. Nat. (Paris) 1, 19: 103 (1830)

Aquatic or semiaquatic plants, rooted. Rhizome erect. Fronds few, clustered, dimorphic; sterile blades pinnate to 2 pinnate, blades deltate to obovate, usually proliferous; fertile blades longer than the sterile ones, 2-3 pinnate, pinnae narrowly longer than the sterile ones, 3-4 pinnate, narrowly divided, margins enrolled. Sporangi in 1-3 rows.

Areas of free water, floating in quiet waters or rooted in mud. South Africa (Natal), Swaziland, Botswana, Mozambique, Zimbabwe, Angola, Zambia and tropical Africa, including $\mathrm{W}$ Senegal and $\mathrm{N}$ Sudan. Also
Madagascar, Socotra, Saudi Arabia, Iraq, India and Burna. OKavango Delta: Recorded in several permanent swamps. Vouchers: Smith 351 (PRE) (figs. 3, 4).

\section{Adiantum L.}

Rhizome erect, short, or widely creeping, scales brown. Fronds clustered or spaced, monomorphics, blades erect or drooping, 1-4 pinnate; pinnules dimidiate or cuneate, glabrous or pilose, terminal pinnules articulated. Sporangia marginal, borne along the distal veins or on the underside of the reflexed margin of the lobes.

A cosmopolitan genus of over 200 species, specially in South America. One species occurs in the Okavango Delta.

\section{Adiantum capillus-veneris L., Sp. Pl. 2: 1096 (1753)}

Rhizome creeping, light brown; scales lance-linear. Fronds ascending or pendant, 20-50 cm long; stipes shorter or longer than the blades, lustrous purple-black, glabrous; blades lanceolate to ovate, $10-30 \mathrm{~cm}$ long, 2-3 pinnate; pinnae spreading, alternate, terminal pinnae variable in size and shape. Sori solitary in the lobes, oblong-lunate.

Rock crevices, boulders falls with shallow soils and river banks. Found in places continuously moist with deep to slight shade. Cosmopolitan. Widespread in S Africa, Mozambique, Zambia, Zimbabwe, Angola, Malawi, Zaire, Kenya, Uganda, Tanzania, Ethiopia, Sudan, Egypt, Chad, Libya, Algeria, Morocco. Also Madeira, Cape Verde Islands, Madagascar, Mauritius and Comoro Islands. Okavango Delta: Recorded in the Kwando River. Voucher: Smith 4337(PRE) (figs. 3, 4).

\section{Pteris $L$.}

Rhizome erect or creeping, scales linear to ovate. Fronds clustered or spaced; blades membranous or coriaceous, glabrous, 1-4 pinnate; veins free or anastomosing. Sori linear, borne in marginal vein; indusium continuous and formed from the reflexed margin, paraphyses usually present. 

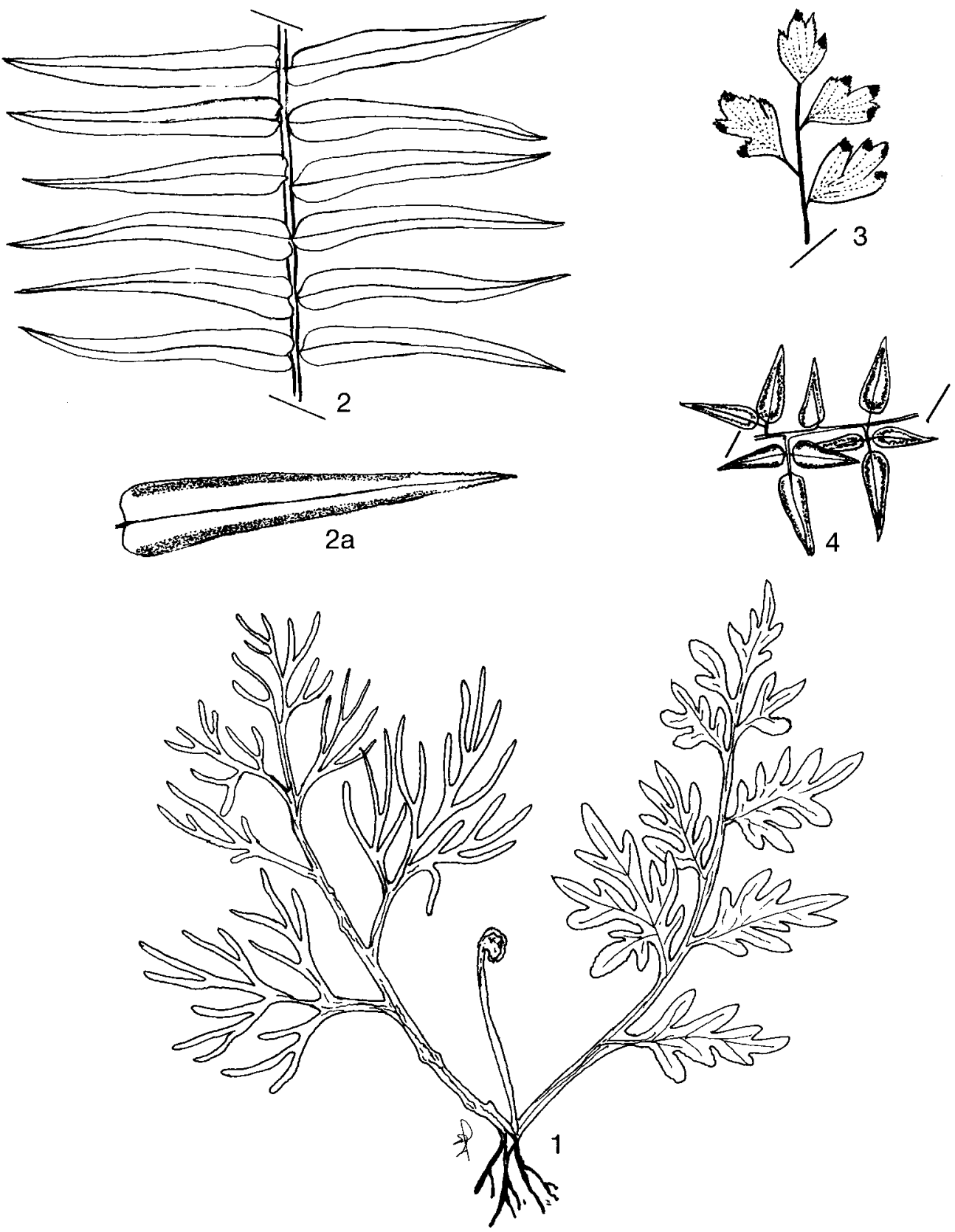

Fig. 3.-Ceratopteris cornuta: 1, plant. Pteris vittata: 2 , segment of frond; $2 \mathrm{a}$, detail of fertile pinna. Adiantum capillusveneris: 3 , segment of fertile pinnules. Pellaea boivinii: 4 , segment of fertile pinnules. 


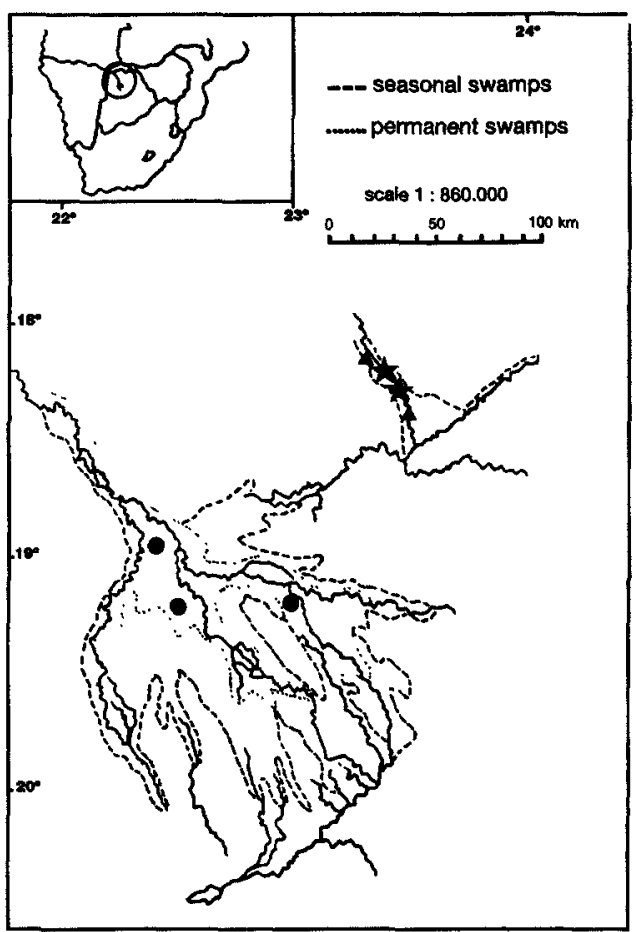

Fig. 4.-Distribution of Ceratopteris cornuta $(\bullet)$, Adiantum capillus-veneris $(\star)$ and Pteris vittata $(\boldsymbol{\Delta})$ in Okavango Delta.

A genus with nearly of 250 species, mostly tropical. One species occurs in the Okavango Delta.

\section{Pteris vittata L., Sp. Pl. 2: 1074 (1753)}

Rhizome creeping,linear lanceolate, scales pale brown. Fronds spaced, erect or arching, membranous; stipe pale brown, terete, up to $12 \mathrm{~cm}$ long; blades elliptic-oblong, simple pinnate; pinnae linear-attenuate, up to $16 \mathrm{~cm}$ long, sterile margins minutely crenate; rachis sulcate, pale brown. Sori in marginal lines, extending most of the length of the fertile pinnae; indusium membraneous.

Clumps, eroded edges and islands, in shade. Paleotropical and paleotemperate regions. S Africa to Angola, Zimbabwe, Mozambique, Zaire, Tanzania, Ethiopia, Sudan, Ghana, Algeria, Cape Verde Islands, Canary Islands, Madagascar, Mauritius, Comoro Islands, Zanzibar, Socotra and
Yemen. Also India, China, Taiwan, Japan, Malaysia, Philippine Islands, New Guinea, New Caledonia, Polynesia and probably Australia. OKavaNGo DELTA: Recorded in the mainstream of the Kwando River. Vouchers: Smith 2349 (PRE) (figs. 3, 4).

\section{Pellaea Link}

Rhizome usually short, creeping; scales lanceolate, castaneous to black. Fronds coriaceous, glabrous, pilose or set with scales; stipes terete or sulcate; blades 1-4 pinnate, segments articulated; veins free or anastomozing. Sori submarginal, confluent into a soral line; indusium continuous, formed from the reflexed margin, paraphyses usually absent.

A genus with about 30 species, most of them in S Africa and S America. One species recorded in the Okavango Delta.

1. Pellaea boivinii Hook., Sp. Fil. 2: 147, t. $118 \mathrm{~A}$ (1858)

Rhizome suberect; scales castaneous to ferruginous, lanceolate attenuate. Fronds erect, coriaceous; stipe terete, scales concolorous; blades deltate, up to $18-14 \mathrm{~cm}, 3$ pinnate, basal pinnae 2 pinnate, pinnules of the mid pinnae narrow oblong-ovate, entire, glabrous, up to $10-3 \mathrm{~mm}$, base articulate, venation free. Sori linear; indusium continuous, erose to entire, membraneous.

Rock outcrops and rock crevices with skeletal soils in full sunshine or very slight shade. It is severely affected during the dry season. South Africa (Transvaal and Natal), N Botswana, Zimbabwe, Zambia. Also Madagascar, Mauritius, Comoro Islands, Sri Lanka and Southern India. OKavango DELTA: Recorded in the Samiki Channel. Vouchers: De Joncheere 288 (PRE), Theron 1812 (PRE), Jacobson 4310 (PRE) (figs. 3, 6).

\section{THELYPTERIDACEAE}

Rhizomes creeping or erect, scales brown or black, non-peltate. Stipes not articulated; blades 1-2 pinnate, rarely 3-4 pinnatifid, 
glabrous, pubescent or pilose; veins free. Sori dorsal in veins or on the tissue between them, round, indusia present or absent, reniform.

One genus occurs in the Okavango Delta.

\section{Thelypteris Schmidel}

Rhizomes slender or creeping. Fronds scattered to fasciculate; blades usually 1 pinnate, rarely 2 pinnate, slightly dimorphic. Sori roundish or elliptic, dorsal in veins, with or without indusium; indusium if present usually roundish-reniform.

The largest genus of ferns with close to a thousand species distributed throughout much of the world (PROCTOR, 1989). Two species occur in the Okavango Delta.

\section{KEY TO THE SPECIES OF THELYPTERIS IN THE OKAVANGO DELTA}

1. Veins joined below the sinus. Sori supramedial, ordered in a zig-zag pattern

1. $T$. interrupta

- Veins free. Sori medial, ordered in a line pattern 2. $T$. confluens

1. Thelypteris interrupta (Willd.) Iwats., J. Jap. Bot. 38: 314 (1963)

Rhizome extensively creeping, branched. Fronds pinnate to 2 pinnatifid, up to $2 \mathrm{~m}$ long; blades lance-oblong, $35-80 \mathrm{~cm}$ long or more, abruptly acuminate at the apex, pinnae linear, incised, with several veins, a pair of them anastomosing below the sinus. Sori supramedial, ordered in zig-zag pattern; indusium orbicular reniform, usually glabrous, margins irregular or erose.

Places regularly flooded and river banks. Forms large colonies, growing in full sunlight, but also growing very well in places with light shade. Pantropical. South Africa (Transkei, Natal, E Transvaal, Cape Province), Swaziland, Botswana, Zimbabwe, Mozambique, Malawi, Zambia, Angola, Zaire, Kenya, Tanzania, Ethiopia, Sudan, Chad, Cameroun, Algeria, Senegal, Zanzibar, Gambia. Also Madagascar and Mauritius. OKavango Delta: It is one of the most common ferns in the Okavango Delta. Recorded in several permanent swamps and Moremi Wildlife Reserve. Vouchers: Bethune 152 B (PRE), Wager 3 (PRE), Gibbs Russell 2144, 2371, 2427 (PRE), Smith 729 \& 1558 (PRE), Biggs $M-112, M-614$ \& M-615 (PRE), Ellis 3045 (PRE), Wild \& Drummond 7104 (PRE), Van Reasburg $B$ 41148 (PRE) (figs. 5, 6).

2. Thelypteris confluens (Thunb.) C.V. Morton in Contr. US. Nat. Herb. 38: 71 (1967)

Rhizome extensively creeping, branched. Fronds 2 pinnate to 2 pinnatifid; blades lanceolate, pinnae linear-lanceolate, with several veins, completely free. Sori circular, ordered in a line and situated in central position between the costa and the margin.

Permanent swamps, shores of lakes and river banks, usually found with grasses, sedges and species of Phragmites and Papirus. Found in full sunlight or very slight shade. South Africa (SW Cape Province) to Zayre, Sudan, Ethiopia as well as Madagascar. Also S India, Thailand, Sumatra, Papua New Guinea, Australia and New Zealand. OKAvanGo DELTA: Recorded in several permanent swamps. Vouchers: Smith 754 (PRE), Gibbs Russell \& Biegel 640616 (PRE), Tinley 1080 (PRE), Edwards 4363 (PRE), Ellis 3070 (PRE), Cresswell 3 (PRE), Ellery 2 (PRE) (figs. 5, 6).

\section{MARSileaceae}

Fronds circinate in bud, long-stipitate and 2-4 foliate, segments with flabellate venation. Fertile plants bearing one or more sessile or stalked capsule-like sporocarps at the base of the stipes or along their lower part. Sporocaps variously septate within, the sori solitary within the compartments, each sorus with two kinds of sporangia: megasporangia each containing a single large megaspore with a mucilage coating, and microsporangia containing numerous minute microspores.

A family with three genera and about 56 species (Proctor, 1989). One genus in the Okavango Delta. 


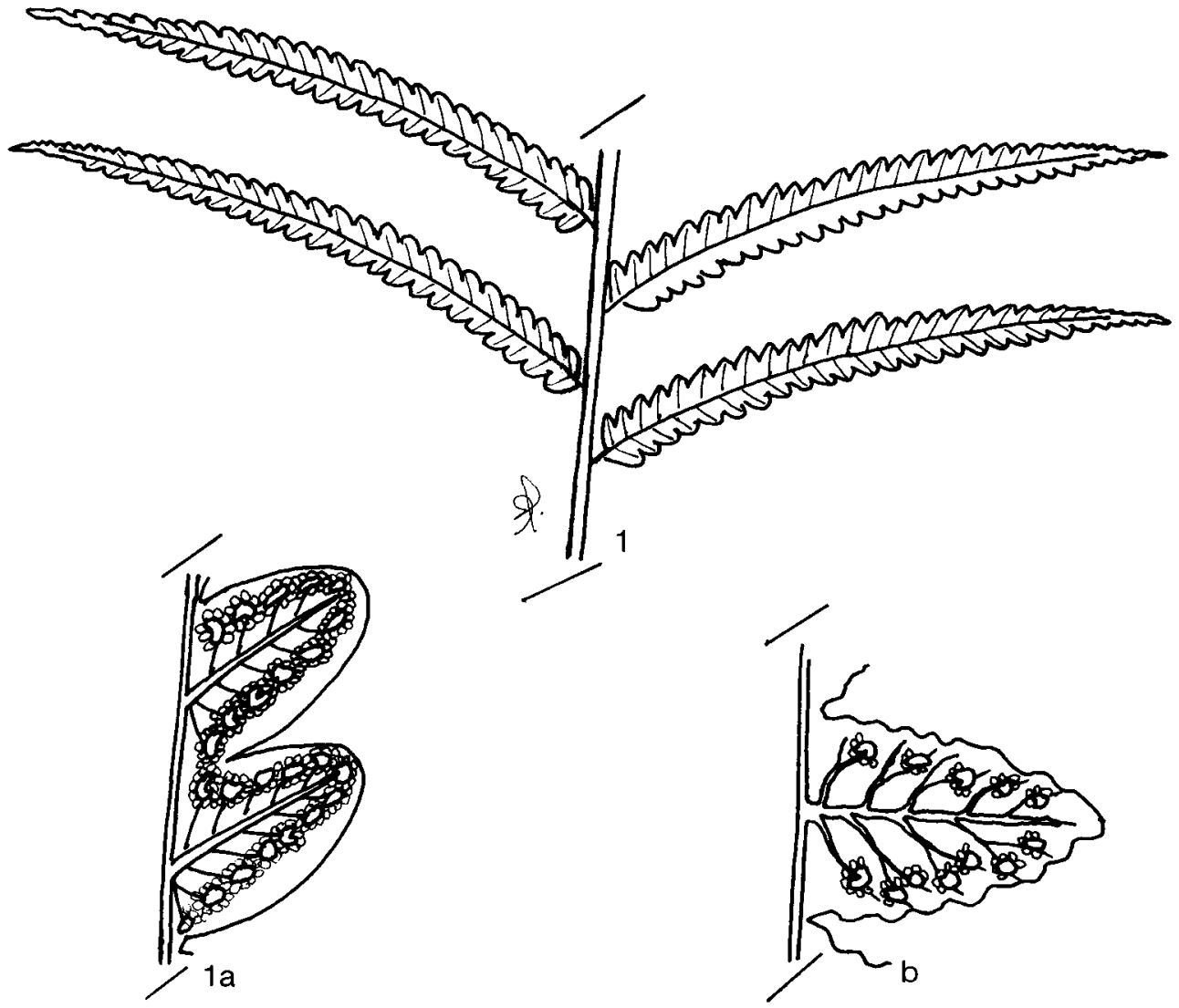

Fig. 5.-Thelypteris interrupta: 1, segment of frond; la, detail of fertile pinna lobes. Th. confluens: $\mathbf{b}$, detail of fertile pinna lobes.

\section{Marsilea L.}

See characteristics of the family.

A genus with about 50 species of worldwide distribution (РROCTOR, 1989). Four species occur in the Okavango Delta.

\section{KEY TO THE SPECIES OF MARSILEA IN THE OKAVANGO DELTA}

1. Sporocarpus dark black, outer layer peeling off with age 1. M. nubica

- Sporocarps brown to dull

2. Pedicels branching repeatedly producing tight clusters of sporocarps with both teeth prominent

2. M. minuta
- Pedicels free ..................................................... 3

3. Leaflets pilose to glabrous, sporocarps growing downwards 3. M. vera

- Leaflets densely silvery villous, sporocarps erect, densely hairy

4. M. villifolia

1. Marsilea nubica $\mathrm{A}$. Br. in Mber. $\mathrm{K}$. Preuss. Akad. Wiss. Berl. 1863: 432 (1864)

Rhizome very slender. Stipes of the floating form up to $35 \mathrm{~mm}$ long; leaflets variable, distal margin sinuate; stipes of the dry land form up to $60 \mathrm{~mm}$ long, leaflets small, margin entire, shallowly irregular. Sporocarps usually single, variable in shape, dark black, usually shiny, with the epidermis peeling off with age; pedicels free, short, 


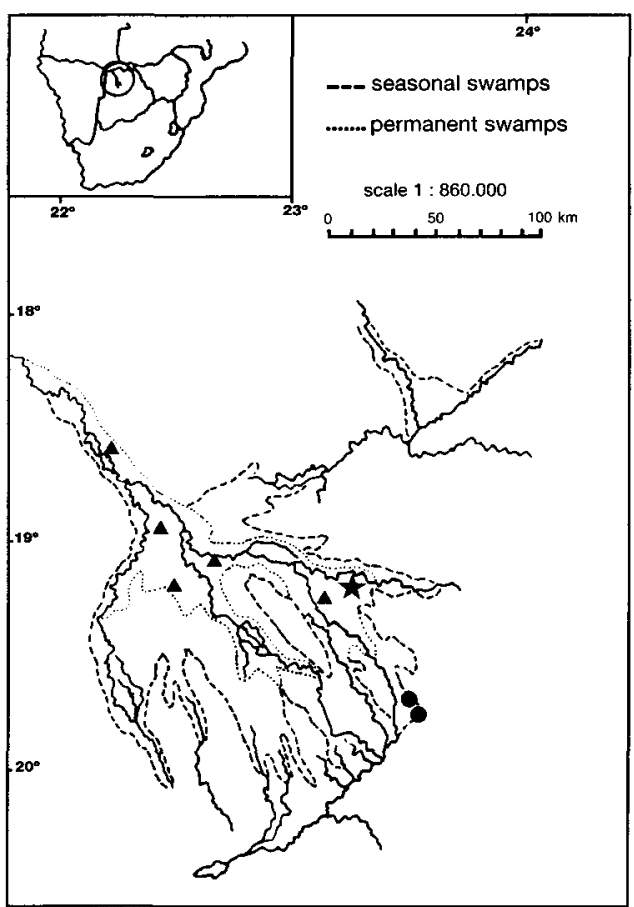

Fig. 6.-Distribution of Pellaea boivinii (•), Thelypteris interrupta $(\star)$ and Th. confluens ( $(\mathbf{)})$ in Okavango Delta.

arising from the stipe axils; superior tooth indistinct; inferior tooth absent or not developed.

This species has two varieties. Only one variety occurs in the Okavango Delta and Botswana.

1a. Marsilea nubica $\mathrm{A}$. Br. var. gymnocarpa (Lepr. ex A. Br.) Launert in Garcia Orta, Ser. Bot., Lisb. 6(1-2): 124 (1983-84)

Sporocarps with the long axis pointing downwards; broadly to narrowly deltate, rarely semicircular in outline; always very dark black and shiny, smooth, with minute dots.

Seasonally flooded pans, ponds and pools. W Zimbabwe, Botswana, Namibia, Angola. Also in tropical Africa and Madagascar. OKaVANGo DelTA: Recorded in the central Boro River. Vouchers: Smith 1819 \& 2041 (PRE), Schweickerdt 2180 (PRE) (figs. 7, 8).
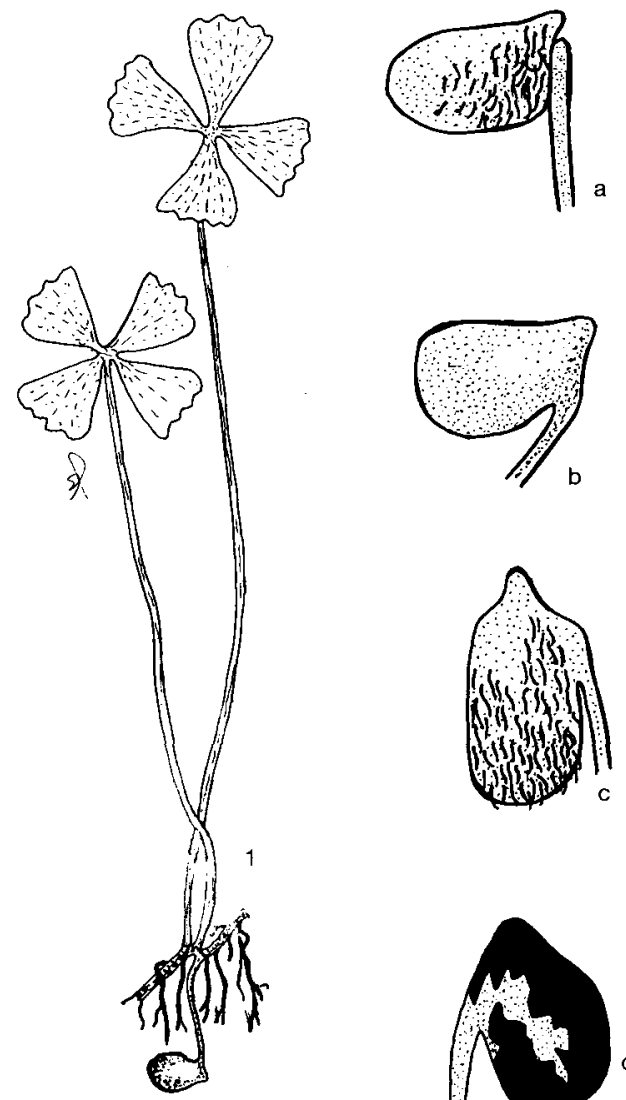

Fig. 7.-Marsilea villifolia: 1, part of plant; c, sporocarp in lateral view. $M$. minuta: a, sporocarp in lateral view. $M$. vera: $\mathrm{b}$, sporocarp in lateral view. $M$. nubica: $\mathrm{d}$, sporocarp in lateral view.

2. Marsilea minuta L., Mant. Pl. Alt.: 308 (1771)

Rhizome slender, long-creeping, glabrous. Stipes of the floating form up to $240 \mathrm{~mm}$ long; leaflets glabrous, obovate, distal margins rounded, entire or shallow irregular; stipes of the dry land form up to $130 \mathrm{~mm}$ long, leaflets thinly pilose, obovate, distal margins entire or sinuate. Sporocarps 2-5 per cluster, or rarely solitary, variable in shape, densely pilose but becoming glabrous with age, elliptic in dorsoventral cross section, dark brown to almost black, without dorsal or ventral furrow; teeth very prominent. 


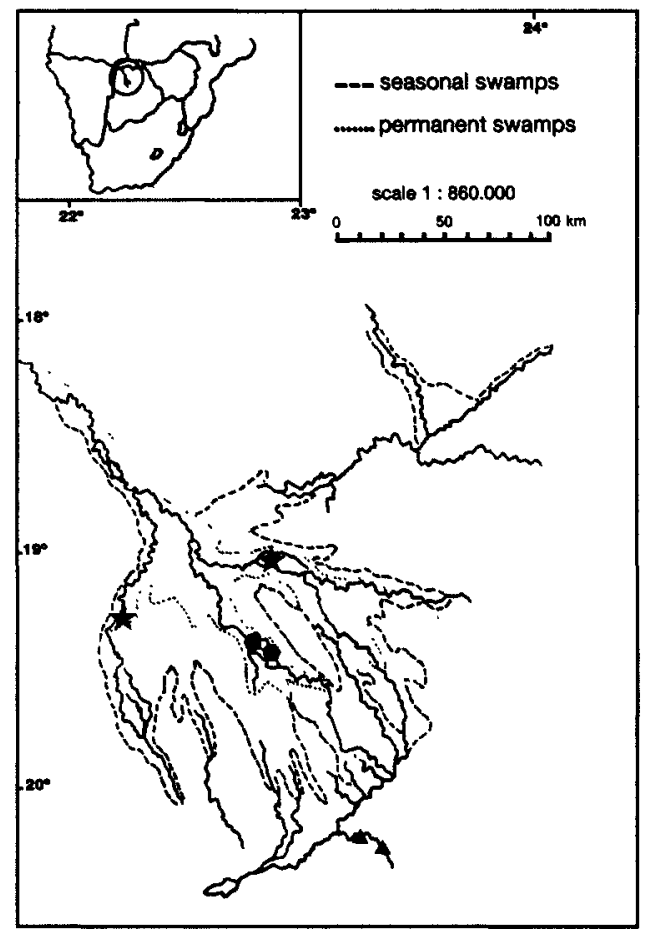

Fig. 8.-Distribution of Marsilea nubica (๑), M. minuta $(\star)$ and $M$. vera $(\Delta)$ in Okavango Delta.

Seasonally flooded pans, ponds and swamps in the Okavango Delta. South Africa (N Natal), Botswana, Zimbabwe, Mozambique, Zambia, Malawi, Angola and widespread through Africa to Guinea Bissau and Algeria. Also Madagascar, Comoro Islands and India. OKavango DELTA: Recorded in Xhere Island and Thaoge River. Vouchers: Smith 652 (PRE) (figs. 7, 8).

3. Marsilea vera Launert in Mitt. Bot. St. Samml., Münch. 3: 505 (1960)

Rhizome stout, strongly branched. Stipes of the floating form up to $250 \mathrm{~mm}$; leaflets obovate to obdeltate, distal margins entire to slightly irregular, glabrous; stipes of the dry land form up to $200 \mathrm{~mm}$ long; leaflets narrow, minutely pilose to glabrous. Sporocarps growing downward, brown to dull, densely pilose; pedicels free, arising from the axis; superior tooth short, conical, obtuse; inferior tooth absent.
Seasonally flooded ponds, pans and woodland savannas, usually on sandy soils. Namibia, Botswana and Zimbabwe. OKavango DELTA: Recorded near the Boteti River. Vouchers: Smith 1231 (PRE), Schweickerdt 2200 (PRE) (figs. 7, 8).

4. Marsilea villifolia Brem. \& Oberm. ex Alston \& Schelpe in J. S. African Bot. 18: 566, 166 (1952)

Rhizome stout, densely villous at nodes. Stipes robust, $180 \mathrm{~mm}$ long. Leaflets broadly obdeltate, villous or tomentose; margin crenate, shallowly lobate. Sporocarps erect, solitary, brown to dull, rectangular in dorsiventral cross-section, densely pilose, glabrous with the age; pedicels free, short, arising from the axels; superior tooth not very conspicuous, conical or obtuse; inferior tooth absent or a shallow hump.

Seasonally flooded ponds, pans and along rivers. South Africa (N Cape Province and C Transvaal), Botswana and Namibia. OKAVANGO DELTA: Recorded in Qangwa watercourse and Tsau-Xai Xai. Vouchers: Type; G. Van Son 1801 C (PRE, iso!), Smith 2007 (PRE), Hansen 3232 (PRE) (figs. 7, 9).

\section{Salviniaceae}

Small floating plants with dorsoventral structure. Stems horizontal, bearing fronds in whorls of three, two of them green, entire, the third leaf submerged, finely dissected and hairy. Floating fronds with a reticulate venation, the upper surface covered by erect papillae, the under-surface with septate hairs. Plants monoecious, sori in clusters on the submerged frond.

A family with one living genus.

\section{Salvinia Séguier}

A widely distributed genus of about ten species (PROCTOR, 1989). Only one species occurs in the Okavango Delta.

1. Salvinia molesta D.S. Mitchell in Fern Gaz. 10: 251 (1972) 
Rhizome horizontal, bearing fronds in whorls of three, two of them floating, the third one submerged. Floating leaves up to $25 \mathrm{~mm}$, obovate to orbicular, upper surface covered by multicellular hairs, lower surface sparsely covered by hairs; submerged leaf finely dissected into several root-like segments, bearing sporocarps. Sporocarps spherical to ovoid arranged in two rows.

Areas of free waters or forming great mats on still water. This species is one of the most important aquatic weeds in S Africa and its populations in Botswana needs to be controlled. Introduced from tropical America to $C$ and S Africa. Also India, Sri Lanka, Australia and Indonesia. OkaVango Delta: Recorded in Chove River and Kasane. Vouchers: Type, Mitchell 1330 (SRGH, holo!, PRE, iso!), Smith 1165 (GAB, SRGH) (fig. 9).

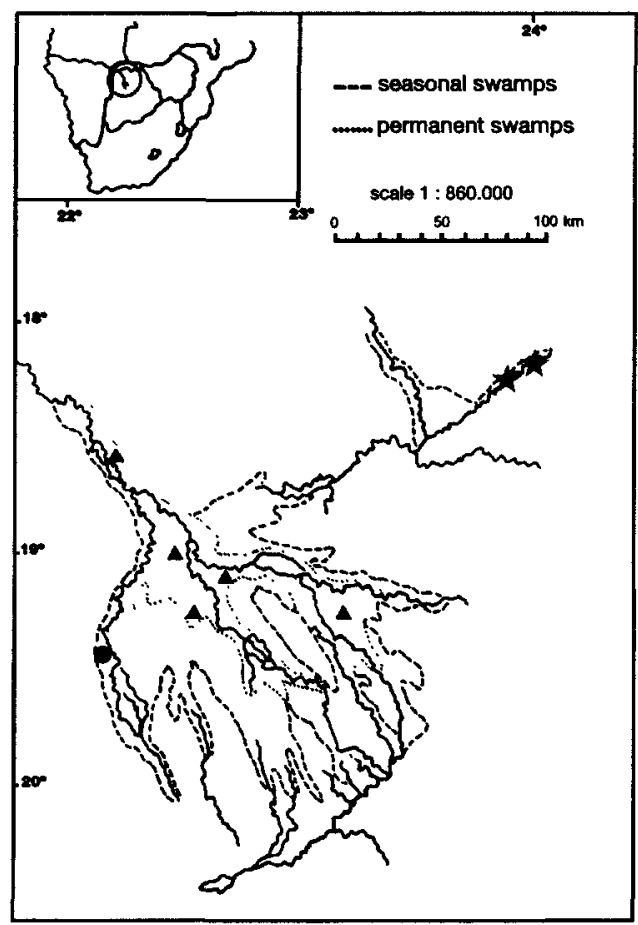

Fig. 9.-Distribution of Marsilea villifolia (•), Salvinia molesta ( $\star$ ) and Azolla pinnata subsp. africana ( $\mathbf{\Delta}$ ) in Okavango Delta.

\section{AzollaCEaE}

Small or minute, floating or subaquatic, heterosporous plants. Growth habit dorsoventral, stems branching pinnately or dichotomously, baring stems and roots. Fronds imbricate, alternate in two rows, each frond divided into two lobes, the lobes opposed, unequally developed, the upper ones covering the stem, with a cavity filled with mucilagenous material containing filaments of symbiotic cyanobacteria, the lower ones submerged, without cavities. Sori born in pairs on submerged frond lobes, each pair consisting of two microsporocarps, or two megasporocarps.

A family with a single genus.

\section{Azolla Lam.}

A widespread genus of seven species (LuMPKIn \& PluCKNetT, 1982). A single species occurs in the Okavango Delta.

1. Azolla pinnata R. Br., Prodr. Fl. Nov. Holl.: 167 (1810)

This species has three subspecies (SAunders \& Fowler, 1992). One subspecies occurs in the Okavango delta.

1a. Azolla pinnata $\mathrm{R}$. Br. subsp. africana (Desv.) R.M.K. Saunders \& K. Fowler, Bot. J.Linn. Soc. 109: 329-357 (1992)

Floating plants, minute. Rhizome horizontal up to $25 \mathrm{~mm}$ long, pinnately branching, triangular to ovate shape, up to $15 \mathrm{~mm}$ wide. Roots single or in fascicles. Leaves 2 lobed, dorsal lobe ovate to elliptic, apex acute; ventral lobe similar to dorsal lobe, but translucent.

Free waters of pools, back-waters of rivers and permanent swamps, in full sunlight or slight shade. Tropical Africa, from Gambia and Senegal to Kenya and Tanzania, and from Chad and Sudan to South Africa (Transvaal) and Botswana. Also in Madagascar. OKAVANGo Delta: Recorded in the Kwando River (Caprivi Strip) in Namibia, in the Botswana border, and in several permanent swamps of 
the Okavango Delta. Vouchers: Edwards 4317 (PRE), Gibbs Russell 2386 \& 2817 (PRE), Smith 209, 2678 (PRE, SRGH) (fig. 9).

\section{ACKNOWLEDGEMENTS}

We would like to sincerely thank $R$. Glen, $\mathrm{L}$. Fish and M. Koekemoer for the use of material in the National Herbarium of Pretoria, and also thank T.T. Aye, T. Mahachi and S. Mpuchane for use of the herbarium in the University of Botswana. We also acknowledge the assistance of J.M. Wells of the US Department of Agriculture, Philadelphia, PA for the review of the manuscript.

\section{REFERENCES}

BuRrows, J.E. (1990). Southern African Ferns and Fern Allies. Frandsen Publishers, Sandton, South Africa.

Hennipman, E. (1996), Scientific Consensus Classification of Pteridophyta. In: J.M. Gibby \& R.J. Johns (ed.), Pteridology in Perspective: 191-202. Royal Botanic Gardens, Kew, London.

Hutchins, D.G., L.G. Hutton, S.M. Hutton, C.R. JONES \& E.P. LOENHERT (1976). A summary of the geology, seismicity, geomorphology and hydrogeology of the Okavango Delta. Geol. Survey Botswana, Bull. 7: 1-27.

LAUNERT, E. (1968). A monographic survey of the genus Marsilea $\mathbf{L}$. The species of Africa and Madagascar. Senckenb. Biol. 49: 273-315.
LAUNERT, E. (1983). A revised key to and new records of African species of the genus Marsilea. Garcia de Orta, Ser. Bot. 6: 119-140.

LUMPKIN, T.A. \& D.L. PLUCKNETT (1982). Azolla as a Green Manure: Use and Management in Crop Production, Westview Press, Boulder, $\mathrm{CO}$.

McCarthy, T.S., W.N. Ellery \& L.G. STanistreet (1993). Lakes of the northeastern region of the Okavango Swamps, Botswana. Z. Geomorph. N. F. 37: 273-294.

PROCTOR, G.R. (1989). Ferns of Puerto Rico and Virgin Islands. The New York Botanical Garden, New York.

Ross, K. (1992). Jewel of the Kalahari Okavango. BBC Books, London.

SAUNDERS, R.M. \& K. FOWLER (1992). A morphological taxonomic revision of Azolla Lam. section Rhizosperma (Mey.) Mett. (Azollaceae). Bot. J. Linn. Soc. 109: 329-357.

SCHELPE, E.A.C.L.E. (1970). Pteridophyta: Mozambique, Malawi, Zambia, Rhodesia, Botswana. In: A.W. Exell \& E. Launert (eds.). Flora Zambeziaca. Crown Agents, London.

SCHELPE, E.A.C.L.E. \& N.C. ANTHONY (1986). Pteridophyta. In: Flora of Southern Africa. Government Printer, Pretoria, South Africa.

SiLITSHENA, R.M.K. \& G. MCLeOD (1992). Botswana a physical, social and economic geography. Botswana.

SMITH, P.A. (1976). An outline of the vegetation of the Okavango drainage system. Okavango Delta Symposium: 93-112.

Vega Hernández, E., R. Caudales, \& A. SánchezPÉREZ (1997). New records of pteridophytes for Botswana. Am. Fern J. 87: 127-130.

Editado por Santos Cirujano Aceptado para publicación: 19-I-2000 